\title{
A STUDY OF WOMEN MANAGER'S SUCCESS FACTORS IN MULTINATIONAL ORGANIZATION - FROM BANGLADESH PERSPECTIVE
}

\author{
Farhad Hossain \\ Assistant Professor \\ Department of Business Administration \\ Leading University, Sylhet, Bangladesh \\ E-mail: farhad@lus.ac.bd
}

\begin{abstract}
Women are getting an imperative part of the full population. However, women involvement is very insignificant in Bangladesh. In the last two decades, Bangladesh has experienced rapid economic growth. Economic growth has led to an upsurge in demand for managers and professionals. According to the Bangladesh Bureau of Statistics, the female labor force participation rate increased to $40 \%$ in 2019, compared to 4\% in 1974. This change is much faster than the growth of the male labor force. Especially in Multinational Company women are now showing their talent and they occupy many upward posts in their career advancement. The key purpose of this paper is to find out the factors that help women to become a success in MNC's. Many women in our country occupied many important posts in MNC's, particularly in managerial mid-level post their presence is significant. This study use exploratory research to shed light on the various aspects that influence women's actual behavior and performance in top positions, as well as the true reasons for women's advancement to the top of organization. A survey questionnaire is distributed among 100 women managers who are occupied different positions in different MNC's. The methodology employed in this study was quantitative research. To check the questionnaire's validity, the researcher used IBM SPSS Statistics 20. From the results, we get some factors like personal, community, and organizational factors that have a huge impact on their success in MNC's.
\end{abstract}

Keywords: Bangladesh, Factors, MNC, Success Women.

\section{INTRODUCTION}

As we know, once upon a time, Bangladeshi women's obligations included caring for their husbands and children. Women were denied the right to study, conduct commerce, or work. In almost all countries, there were insufficient numbers of women in decision-making positions. Growing awareness of this fact has led to the participation of various interest groups in research and decision-making activities. Independence of 1971 Bangladeshi women began to appear in the workplace. Bangladesh also has some regulations and laws protecting in the workplace for women. Women are increasingly participating in several developing and non-traditional sectors, including hotels and restaurants, transportation, real estate services, telecommunications, finance, and insurance, in addition to the export-oriented textile sector. Early 90's when different MNC's started their businesswomen then starting to keep their feet in MNC's but the rate was insignificant but it was increasing. This is since as opportunities for higher education increase, the prospects for entry of Bangladeshi women into the high-value labor market have expanded. In addition, legislative improvements to enhance gender equality in employment and educational opportunities for women have been implemented. These changes help improve the situation of women. However, as newbies to these services, the number of participating women is still very small. Furthermore, development isn't uniform throughout sectors. The culture of local and Multinational Corporations is not the 
same. Nowadays multinational corporations provide a lot of facilities to their women employees which are not seen in the local company Women managers in the twenty-first century require not only professional recognition, but also a variety of skills such as creativity, good and proactive thinking, right and deep perspective, invention, enthusiasm, and so on. The purpose of this study is to determine the extent to which women are involved in social control efforts in various businesses. Women managers have the same level of education as males. Women executives have the same level of education as men and have been shown to be equally capable, creative, innovative, and competent. They have the potential to be trained and contribute to event activities in the same way that a person does. The following main interventions are recommended to effectively manage this transition: the correct implementation of constitutional and legal provisions, modification of customs and social practices that hinder women's development, institutionalization of women's interests, and development of appropriate counselling courses for female managers. The purpose of this study was for the researcher to learn more about the issues that Bangladeshi women professionals face as they strive to advance in their managerial jobs. This article attempts to solve the following key research questions

RQ1. What factors influence their career success?

RQ2. What is that hindrance that creates a wall between their aspiration and reality?

The researcher reviews some relevant literature, both national and international company on women managers, their success factors, their problems, etc.

\section{RESEARCH OBJECTIVE}

The study's goal is to figure out what elements contribute to women's success in multinational companies in Bangladesh.

\section{POST-INDEPENDENCE ERA}

The state of women in Bangladesh in the 1980s was much worse than men. Acute poverty margin seemed more difficult in women. While the medical care, education, and training of women are limited, the prospects to improve productivity among female groups were lower. Around $82 \%$ of the women lived in rural areas at the end of the 1980s. For most rural women, $70 \%$ were in a small village, tenant, and a homeless home. Many people were paid with workers as seasonal activities, generally harvested, and gently or poor cash salaries. Women in rural areas were carried out in Chula, and to maintain livestock, poultry, and small gardens. But the situation was changing after the '90s Therefore, the labor participation rate of women doubled between 1974 and 1984, but came to about $8 \%$. The wage rate of women in the 1980s was low, generally in the range of 20 to 30 percent of male salary rates. According to the ILO study, Bangladesh had a total workforce of 63.7 million people in 2017 , with 28.4 percent of women (18.1 million) and 71.7 percent of men (45.7 million) employed.

\section{RESEARCH METHOD}

This investigation used quantitative investigation methodology. Potential participants were recognized through researchers' individual and professional contacts.

\section{Sampling}

Because of monetary and time constraints, the women chosen to engage in this study were working in a (1) profit-making international business organization, (2) oversaw subordinates in an executive position, (3) earned a minimum of 600,000tk yearly, and (4) were based in Dhaka. The target population of this study consisted of women managers in Multinational companies who are working mid to top-level positions in different $\mathrm{MNC}$ in Bangladesh. The researcher has selected $10 \mathrm{MNC}$ where women are working at a different level. Here given the list of data collection sampling. 
Table 1. Name of MNC and Quantity of Respondents

\begin{tabular}{|l|l|l|}
\hline SL & Name of MNC & Quantity of respondents \\
\hline 1 & Grameenphone & 20 \\
\hline 2 & Robi and Airtel & 21 \\
\hline 3 & Unilever Bangladesh Ltd & 5 \\
\hline 4 & Reckitt Benckiser BD ltd & 7 \\
\hline 5 & Grey Advertising BD ltd & 5 \\
\hline 6 & Nestle Bangladesh ltd & 8 \\
\hline 7 & P\&G Bangladesh Ltd & 5 \\
\hline 8 & Marico Bangladesh Ltd & 8 \\
\hline 9 & Standard Chartered Bank & 6 \\
\hline 10 & Novartis Bd Ltd & 5 \\
\hline 11 & Apollo Hospital & 10 \\
\hline \multicolumn{2}{|l|}{ Total } & 100 \\
\hline
\end{tabular}

\section{Data Collection Method}

The researcher distributes the questionnaires to the responders through a personal visit and Google sheet. The total number of the respondent is 100 . They are holding different positions of these MNC. Each respondent has one week to complete the questionnaire. Due to Covid-19, it was difficult in some cases to collect information.

\section{LITERATURE REVIEW}

Women's participation in employment has expanded because authorities coverage for making sure identical rights. According to Zhong et al. (2011), the "luck" component does not play a significant influence in climbing professional ladders (Zhong et al., 2011). Factors that influence women's advancement were also discovered in the study. The identities of two facilitators were revealed. External and Character were the two (e.g., hard work, attitude toward work, communication skills, and problem-solving skills). Schreiber (1998) proposed that traditional models that emphasize male occupations cannot fully explain female occupations. The success of women depends on various factors. Factors that facilitate women's job advancement have been discovered in studies. Another investigator $\mathrm{Ng}$ and Pine (2003) found that Female managers consider that the positive correlation between communication skills and professional development is stronger than that of men. But a lot of barriers exist to women's success. Borjalilou et al. (2013) claim that women confront numerous constraints when it comes to balancing career and family life and prioritizing one over the other at any one time. At present many organization creates a bar for the women that are called glass ceiling. Knutson and Schmidgall (1999), the glass ceiling, an artificial barrier that hinders qualified employees from being promoted within their organization. For many women in the workplace, low levels of education and illiteracy limit their possibilities for progress (Hejase et al., 2013). Given that the majority of women leave clerical occupations once they reach a higher level of management, it's critical to comprehend the impact of gender in shifting career goals. Research shows that men are more likely to aspire to senior management positions than women. Brownell (1994) found that counseling is more important to female occupations than men. Women should undertake the same professions as males, but women should be aware that they have "distinct demands" that must be met and accommodated in the workplace. Empowerment is equally important for women's success. Empowering women to participate in economic life is one method to improve women's, families', and community's quality of life (Subramaniam et al., 2013). To gain success communication to all aspects is needed. Female managers believe there is a stronger link between communication skills and 
professional development than men, according to $\mathrm{Ng}$ and Pine (2003). It is difficult for any woman to reach a higher position is not possible with the help of men and organizational support. Both academics and industry leaders should take responsibility for educating women for success, according to Brownell (1994) and $\mathrm{Ng}$ and Pine (2003). Leadership positions are very stressful, requiring a lot of work, long hours of work, and a lot of sacrifices. However, for many women, these jobs occupy the same amount of time as raising children, cleaning the house, cooking, and managing the family (Kiamba, 2008). Henry (2011) suggested that mutual understanding between men and women and bridging possible gaps between their understandings. Now women are given many challenging assignments because the success rate is very high. Women wanted more demanding assignments, greater input into policy and decision-making, a healthy work atmosphere, an equal workload, and employers that recognized their strengths. D. Bhatnagar and V. Nair (Bhatnagar and Nair, 1988). Another factor is parental support which is very essential. According to Budhwar et al. (2005), parents' attitudes (especially those from the urban middle class) have altered dramatically. As a result, an increasing number of females are being sent to school.

\section{SUCCESS FACTORS FROM DIFFERENT RESEARCH}

Most empirical studies on female managers have focused on the issue of why women are not as good as men in management. However, the latest research in the fields of management, sociology, psychology, and women's studies has also studied what factors are conducive to the success of female managers. "Intra-personal, interpersonal, and organizational aspects have a significant impact on women's achievement," according to Agarwal and Datta (2017). Attitudes, knowledge, skills, genetics, and personal qualities are among the components recognized within an individual. A lot of factors were found from different research like passion for the job, personality, charisma, opportunity focus, team player, working experience, education, ability, interpersonal relationship, skills, technology savvy, etc. these increase the productivity for any employee. Education is given more priority for daughters in the middle and upper classes particularly respected jobs today (Kabasakal, 2016). An investigation found that due to the lack of use of this human capital women are far beyond men in the job field. Women's views on career advancement, demographic traits relating to their jobs, and early socialization. Women's views in the workplace include great selfefficacy and a strong drive to succeed (Greenhaus \& Parasuraman, 1993). Comparing men who perform the same type of work with women, it can be observed that women are the same as men, women are engaged in paid work, and it is even reported that compared to men, women invest more. Over time, women's job objectives become more similar to men's. According to Leung and Harmon (1990) and Watts et al. (2014), female students exhibited higher career goals than male students. Studies show that women reluctant to shift their job and want to remain in the same company until their retirement which is the main reason for the career advancement barrier. Some studies found that personality has a great impact on career progress. Professional success and personality development remain relevant throughout adulthood. For example, a man with a selfdirected (conscientious) personal orientation will earn a higher salary in ten years (Kohn \& Schooler, 1982), and increased emotional stability in middle-aged adults is related to significant self-perceived work (Brousseau \& Prince, 1981). Another important factor is leadership style. Due to a lack of leadership women are far beyond their career success in Bangladesh. But those who become successful in our study have a strong leadership style. Depending on the situation they follow democratic or autocratic leadership. To grow in a career, female must have a strong commitment to it and limit the number of children you have. Another important dimension is organizational factors. Different researchers classified organizational factors in a different way that includes advisors, organizational culture, collaboration and teamwork, support from supervisors, co-worker support, personal network, organizational policy. Mentors or coach they always provide a right way for career development. Mentors have a considerable impact on the career advancement of women managers. Flexible work arrangements should be provided by the firm, such as 
introducing changes in working hours, working methods, work locations, vacations/vacations, or childcare centers owned by the company (Shirlaws.com 2011) (Kulkarni, 2002). It should be noted that top management can provide direction, coaching, and professional assistance at the organizational level. In addition, he suggested Women must be trained in essential areas to be promoted and efficiently fill managerial positions, according to Kulkarni (2002). Communication, leadership, decision-making, time management, and confidence-building are some of these skills. Women's career advancement is heavily influenced by social influences. The major two factors of this factor are parental influence and reference group. Organizational family support, such as flexible hours and help with child and elderly care, makes it simpler for women with family responsibilities to hold management positions, and it is possible to increase the number of women interested in senior management roles.

\section{SITUATION OF WOMEN IN MANAGEMENT IN GLOBAL CONTEXT}

Today, women are joining the global workforce as unprecedented members. Women's participation in the labor market has increased as a result of higher levels of education, reduced fertility rates and sectorial shifts. Women represent more than $40 \%$ of the global workforce, around $70 \%$ in developed countries and around $60 \%$ in developing countries. Today, more and more women are graduating, pursuing postgraduate degrees, obtaining professional-technical degrees, and entering business life. With the improvement of the educational level and the social acceptance of gender equality, women become involved in management work. However, cultural and social attitudes continue to dominate women's choice of work. However, women are entering the management sector. In fact, with the expansion of management departments, their participation has increased, which has provided women with more employment opportunities. However, when we look at women in management positions, this percentage is much lower than that of men. Their progress is also slow and uneven. Women are still concentrated on the most unstable forms of work in the world, and breaking the "glass ceiling" seems to be out of reach for everyone except a few. Among managers, senior managers, and senior professionals, men represent the majority, while women are still concentrated in lower-level management positions. Although a small number of women are among the best in the world of work, their position in top management is largely insignificant

\section{WOMEN IN MNC'S}

Multinational companies hunt for fair opportunities to fill high-level positions. The aim is to integrate gender diversity into the Bangladeshi workforce, especially at the very best levels. Headhunting firms are authorized to specifically explore female candidates for managerial positions. To draw in those elusive senior corporate women to hitch their circle, many companies provide $25 \%$ to $30 \%$ (annual salary) for senior consulting fees for hiring women, which is beyond the $15 \%$ to $20 \%$ usually used for recruitment. In addition to the diversification factor, the corporate also hopes to rent more women because they're better at communication and negotiation. They'll bring a singular perspective to the desktop. Additionally, the recent economic recession seems to be beneficial to them: it's believed that they perform better than men in difficult circumstances but can we have enough talented women? Well, men still rule the coop. But this example is slowly changing. Compared with domestic operations, multinational companies have fewer female managers in their foreign affiliates. There has been controversy on whether the absence of women from these positions is because of the dearth of special management skills required for international missions. Within the context of Bangladesh, it's an ongoing fight for women to demonstrate their value inside the office and culture. Regardless of their education, expertise, and awareness, women are perceived to be less competent, capable, and knowledgeable than males. Unfortunately, hypocrisy and pretense persist among our society's so-called educated and intellectual males. They talk a lot about gender equality, but they don't believe it exists. Men would denigrate women regardless of their experience, education, or aptitude in order to establish masculine dominance. A male is acknowledged and appreciated when he says the same thing a girl says at a meeting, while 
a woman's perspective is dismissed and unnoticed. If a woman is assertive and powerful, she may be viewed as a problem inside the system. She could also be slandered because of her organization's stance and position. Despite these obstacles, women are increasingly succeeding in their careers, but at a snail's pace.

Factor Analysis

\section{DATA ANALYSIS AND INTERPRETATION}

For testing the appropriateness of the factor model, Bartlett's test is used.

Table 1. KMO and Bartlett's Test

\begin{tabular}{|l|l|r|}
\hline \multicolumn{2}{|c|}{ KMO and Bartlett's Test } \\
\hline Kaiser-Meyer-Olkin Measure of Sampling Adequacy. & .892 \\
\hline $\begin{array}{l}\text { Bartlett's Test of } \\
\text { Sphericity }\end{array}$ & Approx. Chi-Square & 1245.644 \\
\cline { 2 - 3 } & Df & 190 \\
\cline { 2 - 3 } & Sig. & .000 \\
\hline
\end{tabular}

The Kaiser-Meyer-Olkin is a sampling adequacy metric. Table 1 shows that the KaiserMeyer-Olkin sample adequacy value is.892, which is higher than the required 0.5 for factor analysis to proceed satisfactorily. With 190 degrees of freedom, the approximate chi-square value is 1245.644, which is also rather high. As a result, factor analysis is appropriate in this situation since it satisfies the condition to proceed. The observed significance level for Bartlett's Test of Sphericity is.000, indicating a significant association between variables. As a result, the data set meets the criteria for factor analysis.

\section{Determining the Number of Components}

Table 2. Total Variance Explained

\begin{tabular}{|l|r|r|r|r|r|r|}
\hline \multicolumn{7}{|c|}{ Total Variance Explained } \\
\hline \multirow{2}{*}{$\begin{array}{l}\text { Compon } \\
\text { ent }\end{array}$} & \multicolumn{7}{|c|}{$\begin{array}{c}\text { Initial Eigenvalues } \\
\text { \% of } \\
\text { Variance }\end{array}$} & $\begin{array}{c}\text { Cumulative } \\
\%\end{array}$ & Total & $\begin{array}{c}\text { \% of } \\
\text { Variance }\end{array}$ & Cumulative \% \\
\hline 1 & 9.288 & 46.440 & 46.440 & 9.288 & 46.440 & 46.440 \\
\hline 2 & 2.092 & 10.459 & 56.899 & 2.092 & 10.459 & 56.899 \\
\hline 3 & 1.262 & 6.312 & 63.212 & 1.262 & 6.312 & 63.212 \\
\hline 4 & .972 & 4.862 & 68.074 & & & \\
\hline 5 & .812 & 4.062 & 72.135 & & & \\
\hline 6 & .672 & 3.359 & 75.494 & & & \\
\hline 7 & .592 & 2.958 & 78.453 & & & \\
\hline 8 & .566 & 2.831 & 81.284 & & & \\
\hline 9 & .498 & 2.491 & 83.774 & & & \\
\hline 10 & .478 & 2.391 & 86.166 & & & \\
\hline 11 & .442 & 2.211 & 88.376 & & & \\
\hline 12 & .397 & 1.987 & 90.364 & & & \\
\hline 13 & .383 & 1.917 & 92.281 & & & \\
\hline 14 & .349 & 1.745 & 94.026 & & & \\
\hline 15 & .270 & 1.348 & 95.374 & & & \\
\hline 16 & .251 & 1.253 & 96.627 & & & \\
\hline 17 & .228 & 1.139 & 97.766 & & & \\
\hline
\end{tabular}




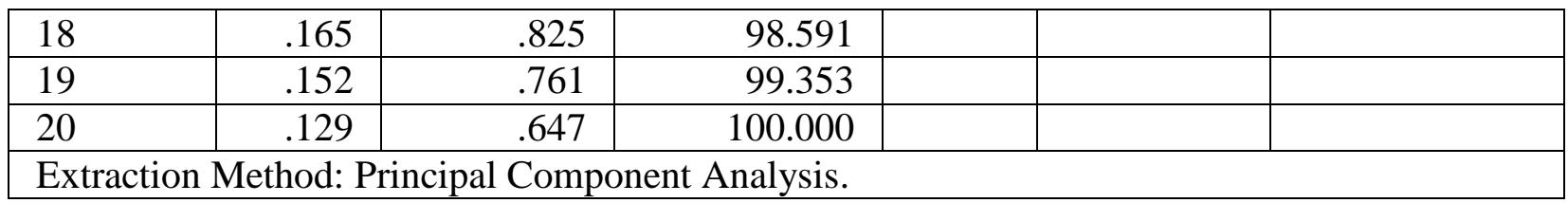

Only three factors have an eigenvalue greater than one, as can be seen in this table. As a result, these three components from a total of 20 variables were used in the analysis. These first three variables account for 63.21 percent of the total variation. Factor 1 is responsible for 46.44 percent of the overall variation (9.29/20). Factor 2 is responsible for $10.46 \%$ of the overall variation, or (2.09/20). Factor 3 is responsible for 6.31 percent of the overall variation $(1.26 / 20)$.

Table 3. Rotated Factor Matrix.

\begin{tabular}{|c|c|c|c|}
\hline \multicolumn{4}{|c|}{ Rotated Component Matrix ${ }^{a}$} \\
\hline & \multicolumn{3}{|c|}{ Component } \\
\hline & 1 & 2 & 3 \\
\hline Job knowledge & .815 & & \\
\hline Ability & .762 & & \\
\hline Skills & .749 & & \\
\hline Education & .740 & & \\
\hline Training & .730 & & \\
\hline Experience & .721 & & \\
\hline Creativity & .708 & & \\
\hline Leadership & .694 & & \\
\hline Attitude & .638 & & \\
\hline Self-motivated & .589 & .403 & \\
\hline Teamwork & & .812 & \\
\hline Supervisor support & & .779 & \\
\hline Co-worker support & & .720 & \\
\hline Work life balance & & .709 & \\
\hline Network & & .700 & \\
\hline organizational policy & & .629 & \\
\hline Family support & & & .873 \\
\hline Reference group & .457 & & .711 \\
\hline Living Standard & .422 & & .621 \\
\hline Role model & .480 & & .538 \\
\hline \multicolumn{4}{|c|}{ Extraction Method: Principal Component Analysis. } \\
\hline
\end{tabular}

This matrix depicts the relationship between the variables and the factors. A large absolute value for the coefficient shows that the factor and the variable are strongly connected. For rotation, the Varimax method was applied.

Table 4. Reliability test

\begin{tabular}{|c|c|}
\hline \multicolumn{2}{|c|}{ Reliability Statistics } \\
\hline $\begin{array}{c}\text { Cronbach's } \\
\text { Alpha }\end{array}$ & $\begin{array}{c}\text { N of } \\
\text { Items }\end{array}$ \\
\hline .930 & 10 \\
\hline
\end{tabular}

\begin{tabular}{|c|r|}
\hline \multicolumn{2}{|c|}{ Reliability Statistics } \\
\hline $\begin{array}{c}\text { Cronbach's } \\
\text { Alpha }\end{array}$ & $\begin{array}{c}\text { N of } \\
\text { Items }\end{array}$ \\
\hline .862 & 6 \\
\hline
\end{tabular}

\begin{tabular}{|c|c|}
\hline \multicolumn{2}{|c|}{ Reliability Statistics } \\
\hline $\begin{array}{c}\text { Cronbach's } \\
\text { Alpha }\end{array}$ & $\begin{array}{c}\text { N of } \\
\text { Items }\end{array}$ \\
\hline .815 & 4 \\
\hline
\end{tabular}




\begin{tabular}{|l|l|l|}
\hline Factor 1 & Factor 2 & Factor 3 \\
\hline .930 & .862 & .815 \\
\hline
\end{tabular}

In this table shows the reliability statistics of these three factors. Here the researcher found that the value of Cronbach Alfa which are greater than .7 it means those questions are correlated strong enough to be considered reliable.

Table 5. Identified factor with variables that affect women entrepreneurship success

\begin{tabular}{|l|l|l|}
\hline \multicolumn{1}{|c|}{ Factors } & \multicolumn{1}{|c|}{ Variables } & Loading \\
\hline Factors 1 & Job knowledge & .815 \\
& Ability & .762 \\
& Skill & .749 \\
& Education & .740 \\
& Training & .730 \\
& Experience & .721 \\
& Creativity & .708 \\
& Leadership & .694 \\
& Attitude & .638 \\
Factors 2 & Self-motivated & .589 \\
Organizational factor & Collaboration and Team work & .812 \\
& Supervisor support & .779 \\
& Co-worker support & .720 \\
& Work life balance & .709 \\
Factors 3 & Network & .700 \\
Community factor & Organization policy & .629 \\
\hline & Family support & .873 \\
& Reference group & .711 \\
& Living Standard & .621 \\
& Role model & .538 \\
\hline
\end{tabular}

\section{FINDINGS OF THE STUDY}

The researcher discovers three elements that determine the success of women managers in Bangladesh based on the above investigation. Personal, organizational, and community variables are the names given to these aspects. A framework can be derived from these data.

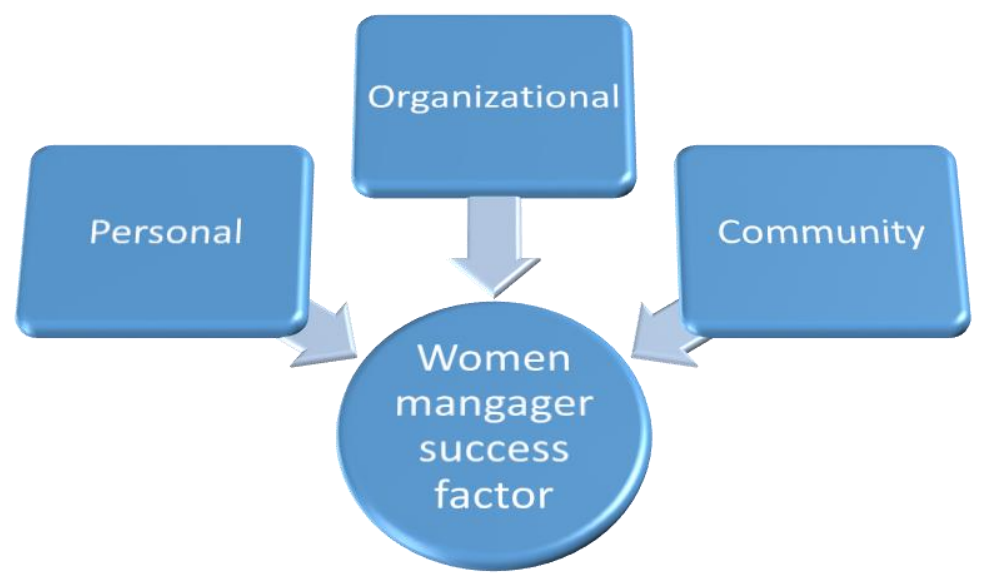

Figure 1. Conceptual framework 
This model depicts the characteristics that contribute to the success of female executives in multinational corporations.

\section{CHALLENGES}

Women encounter numerous, significant, and underreported problems in the job. Women's performance is hampered by a male-dominated company culture, according to Adler (1993). The scope of the problem goes well beyond what we are all aware of. The most significant impediment to women's success is men who are sexist. They enjoy determining a girl's weakness and fragility. Women have broken down many hurdles to reach positions like this, almost reaching the pinnacle of the pyramid. However, in terms of earning payments, promotions, coaching, or entering particular sectors, there is still significant inequality. Hejase et al. (2013) stated while men need to be more attentive, the issue should be examined from a larger perspective. Such a mindset is the consequence of a political process in which both men and women have the ability to substitute the path of women's growth. A social group that does not believe in equality, inclusiveness, or justice will always be an impediment to a progressive and just society in which everyone benefits from growth and wealth. In an extremely backward political environment, we will always face opposition to the implementation of a liberal women's development policy, as well as obstacles to ending child marriage. This emphasizes the need of taking a stand in political, legal, and social systems.

\section{CONCLUSION}

Eventually it can be said that a lot factors are available to induce women for their career progression but if the organization put emphasis on personal, organizational and community variables that will help women to lead in future progress. The present business framework offers women with many chances to further reduce the gap with men. Aside from societal perspective, women demand active structural and human resource guidelines, they seek help from top management, peers and subordinates, and most importantly from themselves. For rectifying present inequalities firms may take active measures. We will always face opposition to the implementation of a liberal women's development policy, as well as obstacles to ending child marriage. This emphasizes the need of taking a stand in political, legal, and social systems. The government should also work to improve women's educational levels by implementing a policy that increases equal access to educational institutions and training, as well as raising awareness and empathy for gender issues.

\section{REFERENCES}

Adler, N. J. (1993). An international perspective on the barriers to the advancement of women managers. Applied Psychology, 42(4), 289-300. https://doi.org/10.1111/j.14640597.1993.tb00745.x

Borjalilou, S., Nazemi, S., Mortazavi, S., \& Rahmanseresht, H. (2013). Reflections of postfeminist viewpoints on female related issues in organizations. Interdisciplinary Journal of Contemporary Research In Business, 4(10), 683-693.

Brownell, J. (1994). Women in hospitality management: General managers' perceptions of factors related to career development. International Journal of Hospitality Management, 13(2), 101-117. https://doi.org/10.1016/0278-4319(94)90032-9

Brousseau, K. R., \& Prince, J. B. (1981). Job-person dynamics: An extension of longitudinal research. Journal of Applied Psychology, 66(1), 59-62. https://doi.org/10.1037/00219010.66.1.59 
Budhwar, P. S., Saini, D. S., \& Bhatnagar, J. (2005). Women in management in the new economic environment: The case of India. Asia Pacific Business Review, 11(2), 179-193.

Datta, S., \& Agarwal, U. A. (2017). Factors effecting career advancement of Indian women managers. South Asian Journal of Business Studies, 6(3), 314-336. https://doi.org/10.1108/sajbs-07-2016-0062

Greenhaus, J. H., \& Parasuraman, S. (1993). Job performance attributions and career advancement prospects: An examination of gender and race effects. Organizational Behavior and Human Decision Processes, 55(2), 273297. https://doi.org/10.1006/obhd.1993.1034

Hejase, H., Haddad, Z., Hamdar, B. H., Massoud, R., \& Farha, G. (2013). Review of "Female leadership: An exploratory research from Lebanon". American Journal of Scientific Research, 86, 28-52. https://doi.org/10.14322/publons.r2117443

Henry, H. M. (2011). Egyptian women and empowerment: A cultural perspective. Women's Studies International Forum, 34(3), 251-259. https://doi.org/10.1016/j.wsif.2011.03.001

Kabasakal, H., Karakas, F., Maden, C., \& Aycan, Z. (2016). Women in management in Turkey. https://doi.org/10.4324/9781315546742

Kiamba, J. M. (2008). Women and leadership positions: Social and cultural barriers to success. Wagadu Volume 6 Journal of International Women's Studies Volume 10: 1, 89.

Knutson, B. J., \& Schmidgall, R. S. (1999). Dimensions of the glass ceiling in the hospitality industry. Cornell Hotel and Restaurant Administration Quarterly, 40(6), 64-75.

Kohn, M. L., \& Schooler, C. (1982). Job conditions and personality: A longitudinal assessment of their reciprocal effects. American journal of Sociology, 87(6), 1257-1286.

Kulkarni, S. S. (2002). Women and professional competency-a survey report. Indian Journal of Training and Development, 32(2), 11-16.

Leung, S. A., \& Harmon, L. W. (1990). Individual and sex differences in the zone of acceptable alternatives. Journal of Counseling Psychology, 37(2), 153.

Mehra, P. (2002). Women managers: to the top and beyond. Hindu Businessline, April, 7.

Meyerson, D. E., \& Fletcher, J. K. (2000). A modest manifesto for shattering the glass ceiling. Harvard business review, 78(1), 126-136.

Ng, C. W., \& Pine, R. (2003). Women and men in hotel management in Hong Kong: Perceptions of gender and career development issues. International Journal of Hospitality Management, 22(1), 85-102. https://doi.org/10.1016/s0278-4319(02)00077-4

Schreiber, P. J. (1998). Women's career development patterns. New Directions for Adult and Continuing Education, 1998(80), 5-13. https://doi.org/10.1002/ace.8001 
Subramaniam, G., Tan, P., Maniam, B., \& Ali, E. (2013). Workplace flexibility, empowerment and quality of life. Procedia - Social and Behavioral Sciences, 105, 885-893. https://doi.org/10.1016/j.sbspro.2013.11.090

Watts, L. L., Frame, M. C., Moffett, R. G., Van Hein, J. L., \& Hein, M. (2014). The relationship between gender, perceived career barriers, and occupational aspirations. Journal of Applied Social Psychology, 45(1), 10-22. https://doi.org/10.1111/jasp.12271

Zhong, Y. G., Couch, S., \& Blum, S. C. (2011). Factors affecting women's career advancement in the hospitality industry: Perceptions of students, educators and industry recruiters. Journal of Hospitality \& Tourism Education, 23(4), 5-13. https://doi.org/10.1080/10963758.2011.10697015

\section{APPENDICES}

\section{Appendix A. Figure 1. Communalities}

\begin{tabular}{|l|c|c|}
\hline \multicolumn{2}{|c|}{ Communalities } \\
\hline Network & Initial & Extraction \\
\hline Team work & 1.000 & .559 \\
\hline Co-worker support & 1.000 & .710 \\
\hline Work life balance & 1.000 & .555 \\
\hline Family support & 1.000 & .663 \\
\hline Supervisor support & 1.000 & .767 \\
\hline Living Standard & 1.000 & .638 \\
\hline Attitude & 1.000 & .682 \\
\hline Self-motivated & 1.000 & .519 \\
\hline Skills & 1.000 & .509 \\
\hline Experience & 1.000 & .596 \\
\hline Creativity & 1.000 & .627 \\
\hline Training & 1.000 & .629 \\
\hline Education & 1.000 & .682 \\
\hline Job knowledge & 1.000 & .660 \\
\hline Role model & 1.000 & .760 \\
\hline Leadership & 1.000 & .550 \\
\hline Ability & 1.000 & .587 \\
\hline Reference group & 1.000 & .737 \\
\hline organizational policy & 1.000 & .734 \\
\hline \multicolumn{2}{|l|}{ Extraction Method: Principal Component Analysis. } \\
\hline
\end{tabular}

\section{Appendix B. Figure 2. Reliability Statistics}

\begin{tabular}{|cc|c|}
\hline \multicolumn{3}{|c|}{ Reliability Statistics } \\
\hline Cronbach's Alpha & N of Items \\
\hline 930 & 10 \\
\hline
\end{tabular}




\begin{tabular}{|c|c|c|c|c|}
\hline \multicolumn{5}{|c|}{ Item-Total Statistics } \\
\hline & $\begin{array}{c}\text { Scale } \\
\text { Mean if } \\
\text { Item } \\
\text { Deleted }\end{array}$ & $\begin{array}{c}\text { Scale } \\
\text { Variance if } \\
\text { Item } \\
\text { Deleted }\end{array}$ & $\begin{array}{l}\text { Corrected } \\
\text { Item-Total } \\
\text { Correlation }\end{array}$ & $\begin{array}{c}\text { Cronbach's Alpha if Item } \\
\text { Deleted }\end{array}$ \\
\hline $\begin{array}{l}\text { Job } \\
\text { knowledge }\end{array}$ & 34.32 & 59.573 & .834 & .916 \\
\hline Ability & 34.35 & 59.866 & .810 & .918 \\
\hline Skills & 34.24 & 64.366 & .692 & .924 \\
\hline Education & 34.38 & 61.874 & .763 & .920 \\
\hline Training & 34.34 & 61.540 & .765 & .920 \\
\hline Experience & 34.44 & 64.289 & .709 & .923 \\
\hline Creativity & 34.37 & 62.801 & .743 & .922 \\
\hline Leadership & 34.35 & 64.492 & .669 & .925 \\
\hline Attitude & 34.27 & 65.532 & .652 & .926 \\
\hline $\begin{array}{l}\text { Self- } \\
\text { motivated }\end{array}$ & 34.38 & 66.420 & .604 & .928 \\
\hline
\end{tabular}

Source: SPSS

\section{Appendix C. Figure 3. Reliability Statistics}

\begin{tabular}{|c|c|}
\hline \multicolumn{2}{|c|}{ Reliability Statistics } \\
\hline Cronbach's Alpha & N of Items \\
\hline .862 & 6 \\
\hline
\end{tabular}

\begin{tabular}{|l|c|c|c|c|}
\hline \multicolumn{5}{|c|}{ Item-Total Statistics } \\
\hline & $\begin{array}{c}\text { Scale } \\
\text { Mean if } \\
\text { Item } \\
\text { Deleted }\end{array}$ & $\begin{array}{c}\text { Scale } \\
\text { Variance if } \\
\text { Item } \\
\text { Deleted }\end{array}$ & $\begin{array}{c}\text { Corrected } \\
\text { Item-Total } \\
\text { Correlation }\end{array}$ & $\begin{array}{c}\text { Cronbach's Alpha if Item } \\
\text { Deleted }\end{array}$ \\
\hline Team work & 20.36 & 12.920 & .701 & .831 \\
\hline $\begin{array}{l}\text { Supervisor } \\
\text { support }\end{array}$ & 20.39 & 12.907 & .686 & .834 \\
\hline $\begin{array}{l}\text { Co-worker } \\
\text { support }\end{array}$ & 20.34 & 13.621 & .601 & .849 \\
\hline $\begin{array}{l}\text { Work life } \\
\text { balance }\end{array}$ & 20.33 & 12.244 & .710 & .829 \\
\hline Network & 20.28 & 13.254 & .639 & .842 \\
\hline $\begin{array}{l}\text { organizational } \\
\text { policy }\end{array}$ & 20.35 & 13.684 & .595 & .850 \\
\hline
\end{tabular}

Source: SPSS

\section{Appendix C. Figure 4. Reliability Statistics}

\begin{tabular}{|c|c|}
\hline \multicolumn{2}{|c|}{ Reliability Statistics } \\
\hline Cronbach's Alpha & N of Items \\
\hline .815 & 4 \\
\hline
\end{tabular}




\begin{tabular}{|l|c|c|c|c|}
\hline \multicolumn{2}{|c|}{ Item-Total Statistics } \\
\hline & $\begin{array}{c}\text { Scale } \\
\text { Mean if } \\
\text { Item } \\
\text { Deleted }\end{array}$ & $\begin{array}{c}\text { Scale } \\
\text { Variance if } \\
\text { Item Deleted }\end{array}$ & $\begin{array}{c}\text { Corrected Item- } \\
\text { Total Correlation }\end{array}$ & $\begin{array}{c}\text { Cronbach's Alpha } \\
\text { if Item Deleted }\end{array}$ \\
\hline Family support & 11.67 & 6.284 & .546 & .808 \\
\hline Reference group & 11.23 & 4.947 & .736 & .718 \\
\hline Living Standard & 11.15 & 4.856 & .672 & .752 \\
\hline Role model & 11.22 & 5.486 & .606 & .782 \\
\hline
\end{tabular}

Source: SPSS

\section{Copyrights}

Copyright for this article is retained by the author(s), with first publication rights granted to the journal. This is an open-access article distributed under the terms and conditions of the Creative Commons Attribution license (http://creativecommons.org/licenses/by/4.0/) 